\title{
PIEE
}

Premise : Journal of English Education and Applied Linguistics https://fkip.ummetro.ac.id/journal/index.php/english

Milaningrum, Damayanti, and Gafur

\section{THE IMPACT OF GUIDED WRITING TECHNIQUE TO DEVELOP STUDENTS' ESP WRITING SKILLS IN BALIKPAPAN STATE POLYTECHNIC}

\author{
By \\ Elisabeth Milaningrum \\ elisabeth.milaningrum@poltekba.ac.id \\ Lilik Damayanti \\ lilik.damayanti@poltekba.ac.id \\ Abdul Gafur \\ abdul.gafur@poltekba.ac.id \\ Balikpapan State Polytechnic, East Kalimantan
}

\begin{abstract}
:
As an action research in nature, the research aimed to test the progress of the students' ESP writing skills when guided writing technique is implemented in writing class and to know the ESP students' attitude towards guided writing technique. This action research is conducted in two cycles. In collecting the data, the researcher uses qualitative and quantitave technique. The qualitative data are obtained from observation, interview, and test analysis. The qualitative data are supported by quantitative data that are the mean score of students' pre-test and posttest on ESP writing. The procedure of guided writing which is implemented in ESP writing class are model paragraph, comprehension questions, language based exercises, oral composition, and written composition. After the analysis of data collected through test items, it was seen improvement in students' ESP writing skills in post-test than in pre-test. The students have shown their improvement such as they are able to construct sentences correctly. They could use appropriate language use when created the pattern of tenses, article, preposition, pronoun, conjunction, and part of speech and also they used better mechanical aspects in writing like capitalization, punctuation, and spelling in post-test than in pretest. Moreover, they can use correct ESP diction on their writing after implemented this technique. The ESP students' attitudes also were enthusiastic and more active involved in ESP writing class.
\end{abstract}

Keywords: ESP, Guided Writing Technique, Writing Skill.

\section{INTRODUCTION}

ESP (English for Specific Purposes) is designed for a particular group of learners having special learning needs for a specific target situation. Meeting the needs and 
making use of the underlying methodology, materials, activities, and assessment techniques of the learners' field of study serve as the absolute characteristics of ESP (Dehnad,\& Hatami, 2010). Chostelidou, D. (2011) states that ESP courses are usually designed to serve stakeholders with different learning goals, and aim to train students to use English in a specific discipline or context. This frame emphasis on learners' specialism and the need to address their target needs requires ESP practitioners to adopt a distinguishable methodology.

As conceptualized by Dudley-Evans and St John (1998) and Hutchinson and Waters (1987), ESP methodology refers to the way and type of interaction between ESP practitioners and learners. Little wood (2014) says that practitioners need to develop an appropriate pedagogy which is sensitive to their own specific contexts, which may stem from their own accumulated classroom experiences giving way to a "teacher-generated theory of classroom practice". The way of undertaking this is to evaluate the methodology component of ESP courses to understand whether they actually match course aims and meet learners' needs.

In Balikpapan State Polytechnic, English lecturer use ESP to teach the students in each major in order to prepare them for entering working field. Because of Balikpapan State Polytechnic is the Vocational School in Higher Education, therefore the outcome have to master ESP based on their major, especially for the students who want to get job in international mining petroleum and gas industry, because they have to join working with the foreigner, bearing in mind that Balikpapan is one of the biggest mining asset in East Kalimantan. There are many international mining companies in Balikpapan. Therefore, the material and teaching methodology in English lecture must be appropriate with the students' need that matches with the students' future. Based on the preliminary research, most of students had problem with their ESP writing skills better than another micro skills, they are: reading, speaking, and listening. Most of students were not enthusiastic to follow an ESP writing class. They felt difficult to construct sentences correctly. They could not use appropriate language use when created the pattern of tenses, article, preposition, pronoun, conjunction, and part of speech. They did not used better mechanical aspects in writing like capitalization, punctuation, and spelling. They could not use correct diction or parts of speech in ESP based on their major 
because of most of them are unfamiliar with these vocabularies in ESP. Moreover, the class situation was not enjoyable and most of the students did not involve in the teaching and learning process.

Ariyanti (2016) states that writing is a complex activity. It is of fundamental importance to learning, to personal development, and to achievement in the education system. Writing is complex activity because the writer should pay attention in choosing and accepting the correct vocabulary, making coherence among sentences from one sentence to the other, explaining the content briefly, and using the correct language use, like tenses, articles, and pronoun. Based on those complex activities, therefore many students in Balikpapan State Polytechnic feel that writing is difficult skills. However along with AFTA (ASEAN Free Trade Area), students need to know how to write an application letters, short message, and electronic mail or even chatting in English with the foreigners.

Writing is one of important skills that need to learn by students as an essential component not only for their academic practice but also later in their workplace (Marcellino, 2008). However, for the students of Balikpapan State Polytechnic, ESP writing is considered as difficult skill. There are some problems faced by the students in learning written text. There are (1) students were unfamiliar with ESP vocabularies /diction based on their major. They felt difficult to produce the diction in their writing; (2) students had problem in term of language use. Some of them did not realize in using the appropriate pattern of tenses, article, preposition, pronoun, and part of speech; (3) students had problem in mechanical aspects; like incorrect capitalization, punctuation, and spelling.

Having these problems of an ESP writing skills, the students then consider that ESP writing is the most difficult. As they think that writing is difficult, surely it affects the ESP students' attitudes while the teaching learning process happened. There are (1) the students do not familiar with ESP vocabularies in their major therefore they have to spent long time to start short paragraph and unfinished it on time. They are difficult to build the ideas, then they did not know what should be written; (2) students wrote all of the paragraphs in Indonesian first, and then they translated it into English. Moreover, some lazy students tend to use goggle translate in their writing. 
There was several problems faced dealing with the students in learning ESP writing. Therefore, it was better to solve those problems with appropriate way of teaching and learning writing. To overcome those problems, the researcher decided to implement Guided Writing Technique to develop students' ESP writing skill. The researcher believed that by using that technique, it could make the students write easily through guided continuous practice. Huy (2015) states that there is a widely held belief that in order to be a good writer, a student needs to write a lot. It means that the poor writers who tend to get failure of their writing; they feel that they are poor writers, so they are not motivated to write and make them seldom to practice since they will be poor writers.

Guided writing involves a lecturer guiding a small group of students in their attempts to create individual written texts, responding to students' attempts, and extending students' thinking during the process. Guided writing is useful for a range of teaching purposes. It allows students to consider purpose and topic when planning their ESP writing. It allows writers to focus on conventions such as spelling, punctuation, standard usage, and handwriting. It also may be used to encourage students to revise and edit their writing. The focus for each session could be on clarifying and extending ideas or organizing and planning the structure of a text. Students' writing can be evaluated during the guided writing process as the lecturer moves around the group. The products can also be analyzed more closely afterwards and used as work samples in portfolios or records of development. Moreover, guided writing also gives the students language based exercises. Lecturer may give the series of exercises which focus on ESP vocabulary building and sentence structure knowledge related to text. Therefore, the students can learn the various vocabularies and practice the correct sentences before they face in the real writing. The students also can generate the idea in oral composition and revise their writing after they have done to write. By passing these stages, the researcher believes that the students will get better in their writing.

Among the studies related to the developing students' ESP writing skill through guided writing technique, a study conducted by Hartanti (2011) investigated the impact of guided writing technique to improve students' writing skill in narrative text for Senior High School students. The finding indicated that guided writing had significant effect for increasing students' writing skill and it can create good 
atmosphere in writing class because the students could motivate their self in their writing. Another study conducted by Ningsih (2016) demonstrated that guided writing can improve the students' writing ability of Junior High School students. Guided writing can overcome the problems in the teaching of writing and the result of post-test is significant better than pre-test. Nevertheless, there have not studies that show improving writing skill for university or polytechnic students especially for ESP writing class. Therefore, this current research was intended to investigate whether guided writing technique can improve students' ESP writing skills in Polytechnic, especially in Balikpapan State Polytechnic. The study tries to answer the research questions below:

1. Does guided writing technique can improve students' ESP writing skill in Balikpapan State Polytechnic?

2. What are the ESP students' attitudes toward guided writing technique?

\section{METHOD}

\section{Design}

The research designed is classroom action research that has aim to overcoming the students' problems in ESP writing skills through guided writing technique and to explore their attitudes towards this technique. According to Wallace (2000), the implementation of Action Research includes four steps as follows:

1. Planning

Develop a plan critically informed action to improve what is already happening.

2. Action

Act to implement the plan.

3. Observation

Observe the effects of the critically informed action in the context in which it occurs.

4. Reflection

Reflecting process on these effects as the basis for further planning, subsequent critically informed and so on, through a succession of a stages. 


\section{Subject or Participant}

The subject of this research is the second semester students of Balikpapan State Polytechnic. This research used one class as the research subject that is ESP students of mechanical engineering department in heavy equipment major that consists of 32 students.

\section{Data and Source of Data}

Based on the pre-observation, the students in mechanical department on heavy equipment major revealed that the students in this class had problem in ESP writing. The students were not fluent or less productive; they were not familiar with ESP diction of their major in mechanical engineering on heavy equipment and also they often made some grammatical mistakes. It was difficult to generate ideas and organize sentences.

\section{Data Collecting Technique (how the data is obtained)}

In this classroom action research, the techniques of collecting the data used by the researcher are interview, observation, and test. The researcher interviewed the students about the way she implemented the material, the problem faced and the equipment's used. The researcher also interviewed the students about their response about implementing guided writing in learning ESP writing process. The researcher did the interview in the beginning and in the ending of the research in order to know the students' response during the lesson. The researcher used semi-structured interview. The researcher made a schedule first before doing the interview, prepared the questions for interview, and also gave the follow-up questions intended to encourage the interviewee to give fuller more detailed responses. The questions are related to the students' ESP writing skills.

Moreover, the observation was done by the researcher with observed and makes field notes of all activities done in the process of teaching and learning. Observations are ways of finding out more about the students' response, students' behavior, and students' activities during the learning process dealing with students' ESP writing skills. To measure the students' improvement, the researcher also gave ESP written test in the end of each cycle. The researcher asked students to write ESP text that is describing a thing and how it works for one of the tools, instrument, and system in mechanical heavy equipment. By analyzing them, the researcher gets information about 
the students' progress in ESP writing and students' responses toward teaching learning process in the writing class.

\section{Data Analysis Technique}

To analyze the data, the researcher used qualitative and quantitative technique. Qualitative data is acquired from observation, and interview. Qualitative data is supported by quantitative data that are the mean score of pre-test and post-test. From the test, the researcher found the comparison of students' achievement before and after the research. The researcher also compared the mean of each test to know whether there is an improvement or not dealing with students' ESP writing skill.

\section{RESULT AND DISCUSSION}

\section{Result}

The research consisted of two cycles. There were five meetings at the first cycle and three meetings in the second cycle. After each cycle was done, the researcher conducted post-test to know the condition of the students' ESP writing skill. In each cycle, the researcher did planning, implementing, observing the action, and reflecting the result of the observation.

In the first cycle, the improvement of students' mastery in ESP writing could be seen on the increasing of mean score from pre-test and post-test in every category such as content, organization, vocabulary, language use, and mechanic. Based on pretest and post-test in cycle one, it can be shown that there is an improvement in each indicator. The improvement was occurred on the content (5\%), organization (8\%), ESP vocabulary (6\%), language use (8\%), and mechanic (7\%). Those improvements indicated that the students' mastery in ESP writing was better than previous. Moreover, the improvement of students' ESP writing competence could be seen on the changing of the mean score. The mean score indicated the average of students' competence in mastering ESP writing. The mean score of the pre-test for 32 students was 55.00 while the mean score of the post-test 1) was 68.00.

During the teaching learning process, it became more active when the researcher used guided writing technique. The class was noisier than before, but the noise came 
from their discussion while doing the task and curiosity to ask anything about their writing. The students were active. Moreover, several students even came to researcher to ask about some difficult vocabulary. Every student participated in group discussion, although several of them did not give full attention.

On the other hand, the researcher still found some problems experienced by the students in cycle 1 as follows: (1) Students still have problem in exploring their ideas directly; (2) Students were still unfamiliar with variety of ESP vocabularies/ diction in order to enlarge their vocabulary;(3) Some of students were less productive while joining in group discussion. Although, the result showed that there was an improvement in language use, it does not mean that the students mastered the grammar structure perfectly. Some of them were still poor in making sentence especially when producing a passive form. Therefore, the researcher decided to take the second cycle in order to make better improvement of the students' writing skill.

In the second cycle, the researcher did revising the plan, implementing the action, observing the action, and reflecting the result of the observation. The result of the second cycle showed that students have the better attitude in ESP writing class. It could be seen from their activeness and participation in doing task not only in individual work, but also in group work during the teaching learning process. In the student's score point of view, their score had increased step by step. The students had fulfilled the target; therefore the researcher decides to stop the cycle.

Based on pre-test and post-test in cycle 2, an improvement was occurred on every category such as: content, organization, vocabulary, language use, and mechanic. The highest improvement was on ESP vocabulary ( $17 \%$ ), followed by language use $(16 \%)$, content (11\%), organization (10\%), and mechanics (8\%). Those improvements indicated that the students' mastery in ESP writing was better than cycle 1. Moreover, concerning with the students' competence, the improvement of students' writing competence could be seen on the improvement of the mean score. The mean score result of the test before cycle two was implemented was 68.00 , while the mean score of the post-test or the test after cycle two was implemented was 78.50. It meant that there was an improvement score. The post-test in cycle two showed the improvement result. It was much better than before. Moreover, the writing class situation was more conducive. The situation was quiet while they were writing. They no longer suffered from not 
knowing what they should do. In this case they learned better. They seemed to understand what they should do when they were asked to make composition. Every meeting was better than the previous meeting.

By considering the improvements above, the researcher concluded that guided writing can improve students' ESP writing skills. The students showed better attitude in writing class. It could be seen from their activeness and participation in doing task not only in individual work, but also in group work during the learning process. In the student's score point of view, their score had increased. The students had fulfilled the target; therefore the researcher decides to stop the cycle.

\section{Discussion}

The study tries to answer the research questions as follow: (1) Does guided writing technique can improve students' ESP writing skill in Balikpapan State Polytechnic?, (2) What are the ESP students' attitudes toward guided writing technique?. Based on the pre-research observation, it is found that students' ESP writing skill of Balikpapan State Polytechnic students is still low. A technique which makes them better in ESP writing is guided writing. Guided writing can be defined as a writing process guided by the lecturer limited to structuring sentences, direct answers to questions and language-based exercises which concentrated on vocabulary building, reading comprehension, grammar, and even oral skills that culminates in a piece of writing to build students' writing skill.

Guided writing helps the students write any kind of text preceded with the model paragraph given. In guided writing, students' vocabulary mastery is improved by exercises guided by lecturer. Furthermore sentence structure knowledge as the linguistics aspects in writing is involved so that students have a better preparation to do the writing. The lower levels of language proficiency can be successful use guided writing techniques to build vocabulary and sentence structure knowledge. In addition, students' creative thinking is not fully limited in sentence pattern. Guided writing allows the students to be more flexible in sharing their ideas and thoughts and eventually to deliver their message through their writing. 
Guided writing involves oral preparation practice which makes the class more interesting. It happens because it can be done in different ways according to the students' need and interests. Oral preparation activity in guided writing makes the activity much more interesting and involves the class more. Furthermore, during guided writing activities, the students receive feedback and advice from the lecturer. From those explanations above, it could be concluded that guided writing can improve the students' writing skill.

Based on the related research from Ningsih (2016) showed that guided writing can improve the students' writing ability of Junior High School students. Moreover, Hartanti (2011) that investigated the impact of guided writing technique to improve students' writing skill in narrative text for Senior High School students showed that guided writing had significant effect for increasing students' writing skill and it can create good atmosphere in writing class because the students could motivate their self in their writing. The result of these studies from both of them almost has the same result with this research but the difference is that the topic that was implemented in class. The related research used narrative text for Senior High School students and recount text for Junior High School students, but in my research more specific in ESP text for Polytechnic students. Therefore we can conclude that guided writing can improve students' writing skill either in narrative text and recount text or ESP text.

\section{CONCLUSION AND SUGGESTION}

There are several findings which were resulted from the research. It had been identified that students' writing skill was low as could be seen from the observation result during pre-research and the mean score of pre-test. The pre-research showed that the students were not willing to participate during the teaching learning process, they were unwilling to be active and it can be seen that only certain students followed the lesson well. Guided writing technique is an appropriate technique that can be used by the lecturer in teaching writing to solve the problems. This action research showed that guided writing technique can improve students' ESP writing skill.

The effect of using guided writing technique in the process of teaching ESP writing is that students get the opportunity to more comprehend what they have write. By step by step procedure, the students are introduced the ESP text on manual book of 
their major, then they can comprehend the content of the text, practice the use of grammar and vocabulary, generate the idea, and then implement what they have learnt in the real writing. The students also can revise their writing, and then realize their own errors. Guided writing provides several exercises before the students do the real writing, so that they feel more confident to begin writing.

Guided writing has been proven to be an effective way in improving students' ESP writing skills because it is one of the ways of accustoming students to write. The lecturer should make the students accustom to write, so that they are willing to start writing. To improve students' writing skill, all the students have to practice writing as much as possible. Since writing is a skill gained by practicing, it makes sense to say that the more they practice writing, the better they will write. Students should encourage themselves to learn more, ask what they do not know and learn as much as possible.

\section{BIO-PROFILE}

Elisabeth Milaningrum, M.Pd is an English lecturer in Balikpapan State Polytechnic. She graduated her undergraduate program in English Education, Teachers Training and Education Faculty, Sebelas Maret University in 2011. Then, she continued her post graduate program in the same department and university, graduated in 2013 .She has published articles and presented papers on English language teaching, applied linguistics and research methodology either national or international conferences. She can be reached at elisabeth.milaningrum@poltekba.ac.id

\section{BIO-PROFILE}

Lilik Damayanti, SS.M.Hum is an English lecturer in Balikpapan State Polytechnic. She obtained her Master's degree from Padjajaran University in 2013. Her research interests are English language teaching and learning, applied linguistics, and professional development. She can be reached at lilik.damayanti@ poltekba.co.id.

\section{BIO-PROFILE}

Abdul Gafur, M.Pd is an English lecturer in Balikpapan State Polytechnic. He obtained her Master's degree from Mulawarman University in 2014. His research interests are English language teaching and learning, teacher education and professional development. He can be reached at abdul.gafur@poltekba.co.id. 


\section{REFERENCES}

Ariyanti, A. (2016). Shaping Students 'Writing Skills : The Study of Fundamental Aspects in Mastering Academic Writing. Indonesian Journal of EFL and Linguistics, 1(1), 63-77.

Chostelidou, D. (2011). Needs-based course design: the impact of general English knowledge on the effectiveness of an ESP teaching intervention. Procedia Social and Behavioral Sciences, 15, 403-409. Retrieved from https://www.sciencedirect.com.

Dehnad, A. \& Bagherzadeh, R. \& Bigdeli, S. \& Hatami, K. \& Hosseini, F. (2010). Syllabus revision: a needs analysis Study. Procedia Social and Behavioral Sciences, 9, 1307-1312. Retrieved from https://www.sciencedirect.com.

Dudley-Evans, T. \& St John, M.J. (1998). Developments in English for specific purposes-a multi-disciplinary approach. Cambridge: Cambridge University Press.

Hartanti, D. (2011). Implementing Guided Writing To Improve Students' Writing Skill In Narrative Text. Undergraduate Thesis, English Department. Surakarta: UNS Press.

Huy, N. T. (2015). Problems Affecting Learning Writing Skill of Grade 11 at Thong Linh High School. Asian Journal of Educaitonal Research, 3(2), 53-69.

Littlewood, W. (2014). Methodology for teaching ESP. In Bhatia, V., \& Bremmer, S. (Eds.), The Routledge Handbook of Language and Professional Communication. (pp. 287-303). New York, NY: Rutledge.

Marcellino, M. (2008). English Language Teaching in Indonesia: A Continuous Challenge in Education and Cultural Diversity. TEFLIN Journal, 19(1), $57-69$.

Ningsih , S. (2016). Guided Writing to Improve the Students Writing Ability Junior High School Students. Indonesian Journal of EFL and Linguistics, 1(2), 129140 .

Wallace, M. J. (2000). Action research for language teacher. Cambridge; Cambridge University Press. 